\title{
IMPROVING STUDENTS' ABILITY IN WRITING RECOUNT TEXT USING DIARY AT ONE OF JUNIOR HIGH SCHOOL IN CAMPAKA - CIANJUR
}

\author{
Yaman Suryaman ${ }^{1}$ \\ ${ }^{1}$ IKIP SILIWANGI \\ 1yamansuryaman@gmail.com
}

\begin{abstract}
In mastering English, students find problems dealing with language skill and language components, most students in Indonesia consider English as a difficult subject wich make them frustrated. Writing is one of the four language skills that plays a very important role in second language learning. Writing skill is more complex and difficult to teach, requiring the mater not only the grammatical and theoretically devices but also the conceptual. One of the equipment aids that can be used in learning writing is a diary. The main objective of this study is to find out whether writing diary improves students' writing skill or not. In this research the researcher used the quantitative method, with classroom action research design. The population of this study was all students of class 8A that consisted of 30 students. Observation, interview, and test as the instruments of this research. The researcher compared achievement of pre-test to identify the effectiveness of using diary writing.
\end{abstract}

Keywords: Diary, Writing Skill, Recount Text.

\section{INTRODUCTION}

In modern era as right now, writing plays an important role in real life. There are several products of writing that human being as social creature need as media to share idea. According to Meyers (2005:2), writing is an action. There are some steps in writing process, they are process of discovering and organizing the idea, writing or putting them on paper, reshaping and revise the writing.

Based on those fact, English learners especially learners at junior high school level must master it besides speaking. As a basic skill in English language, writing skill could not be separated from educational sector. The main reason, English learners at school must be able to express their ideas or feeling in spoken or written forms effectively.

Besides that, the students' motivation to write was low. Some students were extremely unconfident and reluctant to write due to some reasons. The main reason was that they thought they had nothing to write and when they had already got the ideas of what to write about, the lacks of vocabulary, grammar, and sentence organization made their ideas could not be properly conveyed. Therefore, most students seemed to be frustrating when they have to write about something.

\section{Writing Skill}

According to Kern (2000:172), writing in functional communication making learning possible to create imagine words of their own design. Writing as one of four language skill is considered as a difficult skill because the writer should make some aspects in writing such as content, organization, purpose, vocabulary, punctuation, and spelling in a balance way.

Blanchard and Root (2003:41), there are two steps in writing process they are prewriting, and writing. All of those steps are important to make our writing better and systematic. 


\section{Prewriting}

Prewriting is the first step ; it is preparation step before writing process. Prewriting gives warming up the brain to gathering the ideas to write about. There are several ways to warn up before we write.

2. Writing

The next step is writing process. The result of brainstorming of clustering in prewriting process is guidance for us to write paragraph. As we write the first draft on your paragraph use the ideas we generate from prewriting as a guide.

\section{Recount Text}

According to Hyland (2009:29), that recount is a kind of genre that has social function to retell event for the purpose or entertaining. The tense that used in recount text is past tense. Social purpose of recount is to reconstruct past experiences by retelling events in original sequences. We can look at the sample of recount in personal letters, police report, insurance claims, and incident report.

Hyland (2004 : 135) state, there are three generic structure of recount. They are;

1) Orientation : provide the setting and produces participants. It provides information about who, where, when.

2) Record of Events : tell what happened, present event in temporal sequence. It is usually recounted in chronological order. Personal comments and / or evaluative remarks which are interspersed throughout the record of events.

3) Re-orientation : optional-closer of event. It is rounds off the sequence of events.

\section{Diary}

According to Beriwal (2009), a diary is a personal record of events that happen over a period of time, usually consist of date of each diary item, and be as brief or detailed as the writer of diary like, record events in the order in which they happened it. Includes descriptions of the events, impressions about the events, feelings triggered, and opinions the writer of diary formed based on the events.

A diary is personal and generally not meant for someone else unless the owner gives permission for it to be shared. Concept of diary is a durst hand record of ideas, impressions, feeling and opinions about the events in person's life. Record the events in the order in which they happen in as brief or as detailed a way as the writer of diary wish.

A written diary consist of one or more sentences and the sentences should have a clear relation with each other. In technical field, the communicative aspect of writing has gained widespread. Attention as writing has become one of the most widely used modes of communication. However the basic skill involved in writing diaries as their private book or in other media, telling about their life. Besides its training the students to write well, this could be made the students closer to their teacher. It can also make the students no separated walls to learn.

\section{METHOD}

Type of the research the writer uses in this research is Classroom Action Reasearch (CAR). Rochiati Wiraatmaja stated, "Classroom action research is how a group of teachers can organize the condition of teaching and learning process from their own experiences, and try the improvement of idea in their learning and teaching, and see the real effect of the effort" (Asep Yoni, S.S, et. al.: 2010: 165-165)

This aim of this research is improving students' ability in writing recount text using diary. There are two cyclus, and each cycles consists of two meetings. 


\section{Planning}

In order to get the optimal result to solve the problems, the writer tries to make a plan in the cycles based on the problems that are faced by the students in writing class especially in recount text in the classroom.

2. Acting

The activity is done based on the planned material, lesson plan and planned steps. The steps in action: when the problems are found in action one (cycle I), the problem must be solved in action two (cycle II). While in teaching learning process, the researcher presents to monitor and evaluate the process and observe whether the teaching learning process is done as it is planned. Observation is very important to do, because it is done to know the student's improvement in learning. Observation is done during the implementation of the action while the students are doing the activities.

3. Observing

Meanwhile the writer as a teacher does the actions, the collaborators observe the process during the lesson. The writer whenever as a teacher or observer keeps on making records or notes of process by making field notes. Moreover, the observers/collaborators are surely having observation checklists on their hands to be filled up during the process.

4. Reflecting

It is the last step. All the actions are evaluated and reflected in the end of each cycle. The writer as a teacher and the collaborators try to analyze the result of the observation and questionnaire to know the effect of using diary media in writing class especially in recount text. In this step, the researcher evaluates the teaching based on the data in interview, the observation during the class, the questionnaire and field notes.

\section{Subject of the Research}

According to Crowl (1996:15), population are groups consisting of all people to whom a researcher wishes to apply the findings of a study. The population of the research is eighth grade students of SMP Rosa Jaya CampakaCianjur. While, samples are subsets of people used to represent populations (Crowl, 1996:15). The samples of the study are class 8A which consist of 30 students.

\section{Instruments}

a. Pre-test

This test is given before the implementing the Classroom Action Research by giving the test to class $8 \mathrm{~A}$ to identify the initial ability. The researcher gave the test in essay from which consist of ten questions.

b. Post-test

The post-test was held to measure the effect of the implementing the Classroom Action Research. The researcher gave post-test after the teaching process was done for both group. The researcher gave the same test as the pre-test. The researcher compared achievement of pre-test to identify the effectiveness of using diary writing. To know the effect of the methods applied, the test was used. It was diary writing test.

c. Observation sheet

Burns (2010) says that an observation sheet is one way to gather observation data using a coding system or checklist thet consists of aspects during teaching learning activity. It is sometimes called systematic or structured abservation (ibid). burns described that it will be better for the researcher to use a simple checklist so that the observer is able to focus on specific issue.

d. Interview

In this study the interview is done to collect data by asking questions to the collaborators who helps in observation during learning and teaching process in writing class especially in 
writing recount text using diary. The interview with collaborators is done after doing learning and teaching process in the cycle 1 and cycle 2.

\section{Data Collection and Data Analysis}

In this research, the writer used the quantitative research approach, so the technique used to get the data which related to the teaching writing. The researcher used gave pretest before the teaching process and gave post-test after the teaching process was done. The researcher compared achievement of pre-test to identify the effectiveness of using diary writing.

Data analysis plays an important role in every cycle of classroom action research because it can be a reflection and revision for planning the next cycle (Burns, 2010). The data were analyzed in two ways: scoring technique and descriptive analysis. Interview and observation sheet were analyzed through descriptive analysis while test was analyzed by scoring technique.

\section{RESULTS AND DISCUSSION}

\section{Results}

The result of the research through using diary in writing recount text indicated that there was an increase in students' motivated the students to improve their ability in writing recount text, from $20 \%$ in the preliminary study to $86.7 \%$ in the second cycle.

Some points that can be concluded from the research is using diary as the source in writing recount text is recommended that the teacher can use diary writing as one of the alternative technique in teaching written recount text. This is because writing starting from their everyday life is actually an example of recount text. Hopefully, there will be further studies observing other advantages of writing diary.

These data can be concluded that using diary motivates the students in writing recount text. In addition, the analysis of the data shows that there is a significant difference of students' achievement in pre-test and post-test. This is proved in cycle 2 students' ability in writing recount text through using diary has shown the target is hoped.

\section{The Result of Students' Achievement (Cycle 1)}

To know the result of students' achievement, first, the researcher needs to calculate the mean score. The mean score derived from the following formula:

$$
\begin{aligned}
& \bar{X}=\frac{\sum \mathrm{X}}{n} \\
& \bar{X}=\frac{2.020}{30}
\end{aligned}
$$

$$
\mathrm{X}=67.3
$$

Then, the researcher calculated the class percentage that's passed the Minimum Mastery Criterion, using the following formula:

$$
\begin{array}{r}
P=\frac{F}{N} \times 100 \\
P=\frac{17}{30} \times 100 \\
P=56.7 \%
\end{array}
$$

\section{The Result of Students' Achievement (Cycle 2)}

The result of post-test 2 showed that the average score of the class increased to 76.3 in which there were 26 students who passed the Minimum Mastery Criterion or KKM 70. 
The calculation of the mean of students' score in writing recount text post-test. The mean score derived from the following formula:

$$
\begin{aligned}
& \bar{X}=\frac{\sum \mathrm{X}}{n} \\
& \bar{X}=\frac{2.290}{30}
\end{aligned}
$$

$$
X=76.3
$$

Then, the calculation of class percentage about the students who passed the Minimum Mastery Criterion (KKM):

$$
\begin{aligned}
& P=\frac{F}{N} \times 100 \\
& P=\frac{26}{30} \times 100 \\
& P=86.7 \%
\end{aligned}
$$

The Interpretation of Analysis Result

Here, the researcher describes the result of CAR in every cycle on the table below:

Percentage of students' grade improvement

\begin{tabular}{|c|c|c|c|c|}
\hline \multirow{2}{*}{ No. } & \multirow{2}{*}{ Cycle } & \multicolumn{2}{|c|}{ Student's Score } & \multirow{2}{*}{ Percentage } \\
\cline { 3 - 4 } & 1 & Lowest & Highest & \\
\hline 1 & 2 & 40 & 90 & $26.3 \%$ \\
\hline 2 & 50 & 100 & $43.1 \%$ \\
\hline
\end{tabular}

Data of Research Result

\begin{tabular}{|c|c|c|c|}
\hline No. & Test Activities & Average & Percentage \\
\hline 1 & Pre-test & 53.3 & $20 \%$ \\
\hline 2 & Post-test 1 & 67.3 & $56.7 \%$ \\
\hline 3 & Post-test 2 & 76.3 & $86.7 \%$ \\
\hline
\end{tabular}

\section{Discussion}

This part covers the discussion of the teaching writing recount text using diary. The discussion is based on how diary media can improve students' ability in writing recount text.

The finding of the research proved that diary can retain students' ability in writing recount text. It can be seen from improvement of the students' score. The students' average score of pre-test was 53.3. After the implementation of using diary media, the average scores of post-test 1 in cycle 1 was 67.3. Then, the researcher continued to the second cycle with the average of post-test 2 were 76.3 or $86.7 \%$ passed the Minimum Mastery Criterion (KKM) 70 as the criterion success determined. Besides, improving the students' score, the implementation of using diary got positive responses from students in their teaching-learning process of writing recount text.

\section{CONCLUSION}

After conducting Classroom Action Research at second grade of SMP Rosa Jaya CampakaCianjur school academic year 2016/2017, it can be concluded that using diary can improve the students' ability in writing recount text. It can be proved from the following facts:

First, related to the students' achievement, there were $86.7 \%$ who passed the Minimum Mastery Criterion (KKM) 70 with the improvement of students' percentage who passed KKM 
was $66.7 \%$. In the pre-test there were only 6 students who passed the KKM. Meanwhile, in the post-test in the cycle 1 there were 17 students who passed the KKM or 56.7\%. Next, in the result of post-test in the cycle 2, there gained 26 or $86.7 \%$ students who passed the KKM in which their mean score of test derived 76.3. So it achieve the criteria of success. Second, the data from the observation showed that the students were more active and participated in the teaching learning process; it could be seen from the improvements of the students' score in the teaching-learning process for each meeting. The last, the result of interview with the English teacher showed that the teacher gave positive responses after the implementation of using diary in writing recount text since it could be an alternative media to be use in teaching recount text. In conclusion, this research was successful in improving the students' ability in writing recount text by using diary. In addition, the students were more active and participated in the teachinglearning process of writing recount text. Therefore, diary can be alternative media for teacher in teaching writing recount text.

\section{REFERENCES}

Arikunto, Suharsimi, (2003). ProsedurPenelitian :SuatuPendekatanPraktek, Jakarta : PT. RinekaCipta.

Arikunto, Suharsimi, et. Al, (2002). PenlitianTindakanKelas, Jakarta : PT BumiAksara.

Arsyad, Azhar, (2008). Media Pembelajaran, Jakarta : PT Raja GrafindoPersada.

Bram, Barli, (1995). Write Well Improving Writing Skills, Yogyakarta :PenerbitKanisius.

Blanchard, Karen and Christine Root, (2003), Ready to Write, New York : Pearson Education, Inc.

Crowl, Thomas K (1996).Fundamentals of Educational Research, New York : Brown \& Benchmark Publisher.

Faulker, Claude W, (1950). Writing Good Sentences, A Functional Approach to Sentence Structure, Grammar and Punctuation, New York :Charler's Son.

Finocchiaro, Mary, (1974). English as a Second Language : from Theory to Practice, New York : Regents Publishing Company.

Grantika, Gita (2011), Improving Students Writing Skill By Writing Diaries Regulary Through Facebook. English Education Program Faculty of Teachers Training and Education Bogor IbnKhaldun University. Bogor Unpublished.

Halliday, M.A.K., \&RuqaiyaHasan, (1984).Language, Context, and Text : Aspects of Language in Social-seiotic Perspective, Hongkong : Oxford University Press.

Harmer, Jeremy, (2004). How to Teach Writing, England : Pearson Education Ltd.

Hartono, Rudi, (2005). Genres of Text, Semarang : UNNES.

Hyland, Ken, (2004). Genre and second Language Writing, The United State of America: The University of Michigan Press.

Kern, Richard, (2000). Literacy and Language Teaching, New York : Oxford University Press.

Maula, M. Y. Minhatul. (2008). The Effectiveness of Using Authentic materials in Teaching recount Text to Improve Students' Writing Abilty. UPI Bandung: an Publisher Paper.

Meyers, Alan, (2005). Gateaways Academic Writing, Effective Sentence, Paragraph, and Essays, Longman.

Oshima, Alice and Ann Hogue, (1997) Writing Academic English, A Writing and Sentence Structure Handbook, New York : Addison-Wesley Publishing Company.

Oxford, (2008). Oxford Learner Pocket Dictionary New Edition, New York: Oxford University Press.

O’Malley, J. Michael and Lorraine valdez Pierce, (1996). Authentic Assessment for English Language Learners, London : Longman. 